\title{
PROBLEMATIKA BAHASA INDONESIA KEKINIAN: SEBUAH ANALISIS KESALAHAN BERBAHASA INDONESIA RAGAM TULISAN
}

\author{
(NOWADAYS PROBLEMS OF BAHASA INDONESIA: AN ANALYSIS OF \\ MISTAKES IN WRITTEN FORMS)
}

\author{
Akmaluddin \\ Institut Agama Islam Negeri (IAIN) Mataram \\ Jalan Pendidikan Nomor 35 Mataram \\ akmalwiya@gmail.com
}

Diterima: 17 Oktober 2016; Direvisi: 17 Oktober 2016; Disetujui: 9 November 2016

\begin{abstract}
Indonesian language has special functions among the Indonesian nation and national life that are Bahasa Indonesia as a national and nation language. On the basis of that functions, Indonesia language is used in official documents in some countries. The language forms shall be used in making official documents are the standardized Indonesia language. As a national language, Indonesian language is used by any levels of community in Indonesia. However, the both functions are not well applied, therefore it creates some Indonesia language problems. Some problems meant are the mistakes in using Indonesian language, either spoken or written. The problems discussed in this research are (1) some of nowadays Indonesian language problems and their solutions, (2) Factors causing the use of Indonesian language in a variety of life usages. The data are collected through observation and documentation. The data are then analyzed by using inductive data analysis. The results of the analysis show that (1) Indonesia language nowadays has some problems in some linguistics features. (2) The mistakes in using Indonesian language are caused by some factors.
\end{abstract}

Key words: Indonesia Indonesian language problems, language mistakes, written forms

\begin{abstract}
Abstrak
Bahasa Indonesia memiliki fungsi yang istimewa di tengah kehidupan berbangsa dan bernegara Indonesia yang ditandai dengan fungsi bahasa Indonesia sebagai bahasa negara dan bahasa nasional. Atas dasar fungsi tersebut, bahasa Indonesia digunakan dalam penyusunan naskahnaskah kedinasan di berbagai lembaga negara. Ragam bahasa Indonesia yang seharusnya digunakan dalam penyusunan naskah dinas adalah bahasa Indonesia standar. Sebagai bahasa nasional bahasa Indonesia digunakan oleh seluruh lapisan masyarakat di Indonesia. Namun, kedua fungsi ini belum sepenuhnya terlaksana sehingga menimbulkan problematika bagi bahasa Indonesia. Problematika yang terjadi pada bahasa Indonesia ditandai dengan adanya kesalahan berbahasa khususnya bahasa tulisan. Permasalahan yang dibahas dalam artikel ini adalah (1) berbagai problematika bahasa Indonesia kekinian dan solusinya, (2) faktor penyebab kesalahan berbahasa Indonesia pada berbagai bidang kehidupan. Pengumpulan data dalam penelitian ini dilakukan dengan metode observasi dan dokumentasi. Analisis data dilakukan dengan teknik analisis data induktif (inductive data analysis). Hasil penelitian menyimpulkan bahwa (1) bahasa Indonesia khususnya ragam tulisan setakat ini mengalami berbagai problematika pada beberapa tataran linguistik, (2) kesalahan berbahasa Indonesia ragam tulisan disebabkan oleh berbagai faktor.
\end{abstract}

Kata kunci: problematika bahasa Indonesia, kesalahan berbahasa, ragam tulisan 


\section{Pendahuluan}

Bahasa Indonesia memiliki posisi yang strategis dalam kehidupan berbangsa dan bernegara Indonesia. Bahasa Indonesia yang sekaligus menjadi identitas kebangsaan Indonesia mengemban dua fungsi istimewa, yaitu sebagai bahasa negara dan bahasa nasional. Fungsi sebagai bahasa negara ini dibuktikan dengan masuknya bahasa Indonesia pada salah satu bab dan pasal dalam konstitusi Negara Republik Indonesia yaitu pasal XV ayat 36 UUD 1945. Dalam pasal tersebut, dinyatakan bahwa bahasa negara adalah bahasa Indonesia. Ayat dalam pasal ini menunjukkan bahwa pada dasarnya bahasa Indonesia memiliki posisi yang sama strategisnya dengan aspek kehidupan lain misalnya ekonomi, agama, dan budaya sehingga perlu dimasukkan dalam konstitusi tertinggi di republik ini. Adanya pasal ini tentunya bukanlah sekadar menjadi pelengkap pasal dalam UUD 1945, namun pasal ini memiliki konsekuensi yang berkaitan dengan kedudukan bahasa Indonesia. Dalam kaitannya dengan fungsi ini, bahasa Indonesia seharusnya dipergunakan dalam administrasi kenegaraan. Misalnya, dokumendokumen, keputusan, surat-menyurat, baik yang dikeluarkan oleh pemerintah maupun lembaga negara lainnya.

Sementara itu, peran bahasa Indonesia sebagai bahasa nasional ditandai dengan fungsi bahasa Indonesia sebagai identitas nasional dan sebagai lambang kebanggaan kebangsaan di samping sebagai alat pemersatu dan perhubungan antardaerah yang memiliki latar belakang yang beragam. Oleh karena bahasa Indonesia sebagai lambang identitas nasional, seharusnya muncul kebanggaan tersendiri pada masyarakat Indonesia untuk terus tetap melestarikan keberlangsungan bahasa Indonesia. Namun, dua fungsi besar bahasa Indonesia ini tidak serta-merta membuat lembaga negara menerapkan kaidah bahasa Indonesia tersebut. Begitu juga halnya dengan sebagian besar warga negara Indonesia yang seolah tidak acuh terhadap bahasa Indonesia. Atas sikap ini, kemudian muncullah problematika dalam bahasa Indonesia yang ditandai dengan berbagai bentuk kesalahan berbahasa Indonesia terutama dalam ragam tulisan.

Dalam penggunaannya, kesalahan-kesalahan berbahasa Indonesia ragam tulisan dalam dokumen atau naskah dinas masih dijumpai. Begitu juga pada tulisan-tulisan lain 
yang dibuat oleh masyarakat tutur bahasa Indonesia secara pribadi. Bentuk kesalahan berbahasa yang dapat ditemukan sangat bervariasi. Misalnya, kesalahan dalam bidang morfologi, kesalahan dalam bidang sintaksis, baik berupa kesalahan pada frasa maupun kesalahan pada klausa, kesalahan dalam bidang semantik, dan kesalahan dalam hal penggunaan ejaan. Semua bentuk kesalahan tersebut harus diperbaiki agar sesuai dengan situasi dan kondisi sebagai wujud pelaksanaan aturan fungsi bahasa Indonesia sebagai bahasa negara dan sebagai bahasa nasional.

Kesalahan berbahasa Indonesia ragam tulisan tidak sepatutnya diabaikan. Hal ini berarti perlu dilakukan perbaikan terhadap kesalahan berbahasa ragam tulisan yang ada untuk menghindari sikap negatif penutur bahasa Indonesia terhadap bahasa Indonesia. Hal lain yang melatarbelakangi penelitian ini adalah asumsi bahwa analisis kesalahan berbahasa ragam tulisan sangat relevan dengan keperluan akademik. Relevansi ini ditandai dengan muatan kurikulum yang ada pada satuan pendidikan menengah. Kurikulum mata pelajaran bahasa Indonesia pada jenjang pendidikan menengah mengajarkan kepada siswa bentuk-bentuk bahasa Indonesia yang baik dan benar. Dengan demikian, hasil analisis kesalahan berbahasa Indonesia ragam tulisan dapat dijadikan sebagai referensi dalam pembelajaran bahasa Indonesia. Hasil analisis tersebut dapat dijadikan sebagai pengembangan bahan ajar pada lembaga pendidikan menengah.

\section{Kerangka Teori}

\subsection{Problematika Bahasa Indonesia}

Peroblematika merupakan kata turunan yang terbentuk dari kata problem. Kata problem sendiri diartikan sebagai (1) persoalan, (2) masalah. Problematika merupakan sebuah istilah yang digunakan untuk menunjukkan suatu permasalahan yang harus dipecahkan (KBBI, 2008:1215). Berdasarkan definisi kedua istilah di atas, dapat ditarik benang merah bahwa sesuatu yang tengah mendapatkan problem atau masalah berarti sesuatu tersebut memerlukan pemecahan. Dalam hal ini, permasalahan tersebut sedang menggejala pada bahasa Indonesia. Dengan demikian, permasalahan yang terdapat dalam bahasa Indonesia tersebut perlu mendapatkan pemecahan atau solusi. 
Problematika atau permasalahan yang terdapat pada bahasa Indonesia terjadi pada berbagai level kebahasaan misalnya: problematika dalam tataran fonologi, tataran morfologi, tataran sintaksis, tataran semantik, dan tataran penerapan EYD. Dalam penelitian ini, problematika yang diamati terjadi pada ragam bahasa tulisan baik dalam konteks formal maupun nonformal.

\section{Problematika}

berbahasa

Indonesia dalam tataran fonologi dapat terjadi baik penggunaan bahasa secara lisan maupun tulisan. Problematika bahasa Indonesia dalam tataran fonologi meliputi: (a) perubahan fonem, (b) penghilangan fonem, dan (c) penambahan fonem (Setyawati, 2010: 23).

Morfologi adalah bagian dari ilmu bahasa yang membicarakan atau yang mempelajari seluk-beluk bentuk kata serta pengaruh perubahanperubahan bentuk kata terhadap golongan dan arti kata (Ramlan, 2001). Problematika dalam tataran morfologi sebagian besar berkaitan dengan bahasa tulis. Problematika dalam tataran morfologi dapat dikelompokkan menjadi kelompok afiksasi, reduplikasi, dan gabungan kata atau kata majemuk. Afiksasi berkaitan dengan penentuan bentuk asal, luluh dan tidaknya suatu fonem, penentuan variasi atau alomorf suatu morfem, dan penulisan morfem. Reduplikasi berkaitan adalah pengulangan bentuk dasar sehingga menghasilkan bentuk gramatik yang baru. Reduplikasi berkaitan dengan cara penulisan dan penentuan bentuk dasar yang diulang. Gabungan kata atau kata majemuk adalah gabungan dua buah morfem dasar atau lebih yang mengandung satu pengertian baru. Kata majemuk berkaitan dengan cara penulisan kata majemuk. Berdasarkan proses perpaduannya, kata majemuk ada yang ditulis serangkai dan ada pula yang ditulis terpisah.

Sintaksis atau yang sering disebut kalimat adalah satuan bahasa terkecil dalam wujud lisan atau tulisan, yang mengungkapkan pikiran yang utuh (Alwi dkk, 2003). Kesalahan berbahasa dalam bidang sintaksis juga sering terjadi dalam kegiatan berbahasa seharihari sebagaimana kesalahan berbahasa pada bidang-bidang yang lain. Penyebab kesalahan dalam bidang sintaksis pun beragam. Adapun penyebab kesalahan berbahasa dalam bidang sintaksis dijelaskan oleh Tarigan dan Sulistyaningsih, (1998) yaitu: pengaruh bahasa ibu, lingkungan, kebiasaan, dan 
kesadaran penutur bahasa itu sendiri. Kesalahan berbahasa dalam berbagai bidang dan dalam berbagai situasi sepatutnya tidak dibiarkan berlarut-larut. Artinya, kesalahan berbahasa tersebut perlu diperbaiki. Problematika bahasa Indonesia dalam tataran sintaksis dapat berupa frasa, klausa, dan kalimat.

Semantik adalah suatu istilah yang digunakan untuk bidang linguistik yang mempelajari hubungan antara tanda-tanda linguistik dengan hal-hal yang ditandainya (Chaer, 2002). Kesalahan berbahasa dalam bidang semantik ditandai oleh beberapa hal sebagaimana yang disebutkan (Tarigan dan Sulistyaningsih, 1998). Indikatorindikator tersebut yaitu: tidak dapat menjelaskan makna yang dimaksud pembicara atau penulis, tidak dapat menggunakan kata-kata dalam kalimat sesuai dengan makna dan fungsinya, tidak dapat menyebutkan sinonim dan antonim kata yang memang pasangannya (Tarigan dan Sulistyaningsih, 1998).

Selain dalam beberapa aspek kebahasaan di atas, problematika berbahasa juga berpotensi terjadi dalam hal penggunaan Ejaan Bahasa Indonesia Yang Disempurnakan (EYD). Ejaan adalah kaidah cara menggambarkan bunyi dalam bentuk tulisan (huruf) serta penggunaan tanda baca (KBBI, 2008). Berdasarkan makna kamus di atas, dapat ditarik simpulan bahwa ejaan bahasa Indonesia yang disempurnakan adalah seperangkat kaidah yang mengatur penggunaan bahasa Indonesia yang baku dalam bahasa tulis maupun bahasa lisan. Bahasa Indonesia memiliki sejarah pembakuan ejaan selama dua kali sehingga ditetapkannya penggunaan Ejaan Bahasa Indonesia Yang Disempurnakan (Chaer, 2007). Problematika bahasa Indonesia dalam tataran penerapan EYD pada ragam tulisan terdiri atas beberapa hal yaitu: pemakaian huruf, penulisan kata, pemakaian tanda baca, dan penulisan unsur serapan (Haimun, 2014).

\subsection{Analisis Kesalahan Berbahasa}

Analisis dapat didefinisikan sebagai penyelidikan terhadap suatu peristiwa yang dapat berupa karangan atau perbuatan untuk mengetahui keadaan yang sebenarnya (KBBI, 2008). Definisi di atas mengandung makna bahwa dalam proses melakukan analisis terdapat aktivitas penyelidikan dengan maksud mengetahui keadaan sebenarnya. Aktivitas penyelidikan ini tentunya dilengkapi dengan tahapantahapan kerja yang prosedural yaitu: pertama, mengklasifikasikan kesalahan 
berbahasa berdasarkan tataran meliputi kegiatan mengumpulkan kebahasaan misalnya bidang fonologi, sampel kesalahan, mengidentifikasi morfologi, sintaksis, wacana, atau kesalahan yang terdapat pada sampel, semantik. Kedua, mengurutkan menjelaskan kesalahan tersebut, kesalahan berbahasa tersebut mengklasifikasikan kesalahan tersebut, berdasarkan frekuensi kemunculannya dan mengevaluasi taraf keseriusan dalam suatu karya. Ketiga, kesalahan itu. Rumusan yang menggambarkan letak kesalahan dan dikemukakan kedua ahli ini secara memperkirakan penyebab kesalahan langsung menyebutkan tahapan yang tersebut. Keempat, mengoreksi kesalahan tersebut serta merekomendasikan solusi perbaikan atas keslahan tersebut (Tarigan dan Sulistyaningsih, 1998).

Berdasarkan definisi di atas, dapat dibuat rumusan tentang analisis kesalahan berbahasa. Dengan demikian, analisis kesalahan berbahasa adalah suatu kegiatan penelaahan terhadap bahasa untuk mengetahui keadaan yang sebenarnya pada bahasa yang dianalisis. Berdasarkan pengertian ini dapat diketahui tujuan analisis kesalahan berbahasa adalah mencari dan menentukan landasan perbaikan terhadap kesalahan berbahasa pada aspek-aspek kebahasaan.

Tarigan dan Sulistyaningsih (1998) menjelaskan bahwa analisis kesalahan berbahasa adalah suatu prosedur kerja yang biasa digunakan oleh peneliti atau guru bahasa yang perlu dilakukan dalam melakukan analisis kesalahan berbahasa. Tahapan yang dimaksud yaitu: (1) mengumpulkan sampel kesalahan, (2) mengidentifikasi kesalahan yang terdapat pada sampel, (3) menjelaskan kesalahan tersebut, (4) mengklasifikasikan kesalahan tersebut, dan (5) mengevaluasi taraf keseriusan kesalahan berbahasa yang telah diklasifikasikan. Tahapan-tahapan kerja ini dapat dijadikan sebagai panduan dalam melakukan kegiatan analisis kesalahan berbahasa.

\section{Metode Penelitian}

\subsection{Pendekatan Penelitian}

Pendekatan yang digunakan dalam penelitian ini adalah pendekatan kualitatif deskriptif karena penelitian ini bertujuan untuk memberikan gambaran atau deskripsi tentang suatu keadaan secara objektif. Sumber data dalam penelitian ini adalah peristiwa 
penggunaan bahasa Indonesia ragam tulisan pada berbagai hal. Data dalam penelitian ini berupa penggunaan bahasa Indonesia ragam tulisan pada papan pengumuman dan papan nama di berbagai tempat, dan jadwal perkuliahan yang di dalamnya terdapat kesalahan berbahasa tulisan. Data dalam penelitian ini dikumpulkan dengan metode observasi dan dokumentasi.

\subsection{Populasi Penelitian}

Populasi adalah keseluruhan subjek penelitian (Arikunto, 2013:173). Dalam kaitannya dengan penelitian ini, penggunaan bahasa Indonesia ragam tulisan pada berbagai media secara keseluruhan adalah populasi. Namun, karena penelitian ini adalah penelitian sampel, peneliti akan memfokuskan pada sebagian dari populasi tersebut untk dibuat sebuah generalisasi.

\subsection{Sampel Penelitian}

Sampel penelitian ini ditentukan berdasarkan random sampling karena dalam pengambilan sampelnya, peneliti memberi hak yang sama kepada setiap subjek untuk memperoleh kesempatan dipilih menjadi sampel. Mengenai jumlah sampel yang diambil, peneliti mempertimbangkan berbagai aspek misalnya kemampuan dilihat dari waktu, tenaga, dan dana. Oleh karena itu, peneliti mengambil sepuluh penggunaan bahasa Indonesia ragam tulisan pada berbagai media.

\subsection{Pengumpulan Data}

Pengumpulan data dalam penelitian ini dilakukan dengan metode observasi dan dokumentasi. Setelah semua data yang direncanakan terkumpul, peneliti melakukan jejak audit. Arikunto (2013: 26) menjelaskan bahwa jejak audit berarti peneliti melakukan penelusuran dengan maksud memeriksa kembali data yang telah diperoleh.

\subsection{Analisis Data}

Analisis data penelitian ini dilakukan dengan menggunakan metode agih. Metode agih adalah metode analisis data dengan alat penentunya justru bagian dari bahasa yang bersangkutan itu sendiri (Sudaryanto, 2015). Metode agih memiliki beberapa teknik antara lain:

a. Teknik Urai Unsur Terkecil 'Ultimate

Constituent Analysis' (UCA)

Teknik Urai Unsur Terkecil dimaksudkan mengurai suatu satuan lingual tertentu atas unsur-unsur terkecilnya. Unsur terkecil yang mempunyai makna biasanya disebut "morfem". Contoh: dijuan, unsur terkecilnya adalah "di-" dan "jual”. 
b. Teknik Pilah Unsur Langsung atau mengurai suatu konstruksi tertentu 'Immediate Constituent Analysis' (morfologis atau sintaksis) atas unsur(ICA) unsur langsungnya. Contoh: Ia pergi ke

Teknik ini berdekatan dengan Jogja ("ia", 'pergi", dan "ke Jogja"). teknik urai unsur terkecil, yaitu memilah

\section{Pembahasan}

\subsection{Problematika Bahasa Indonesia}

\section{dalam Berbagai Tataran}

4.1.1 Problematika Bahasa fonem, (b) penghilangan fonem, dan (c)

Indonesia dalam Tataran penambahan fonem (Setyawati, 2010).

Fonologi Gambar 1 di bawah ini memperlihatkan

Sebagaimana telah dijelaskan adanya kesalahan fonologi dalam ragam pada bagian sebelumnya, bahwa tulisan yang ditulis dalam bentuk problematika bahasa Indonesia dalam spanduk pengumuman jual beli tanah di tataran fonologi meliputi: (a) perubahan sebuah lokasi.

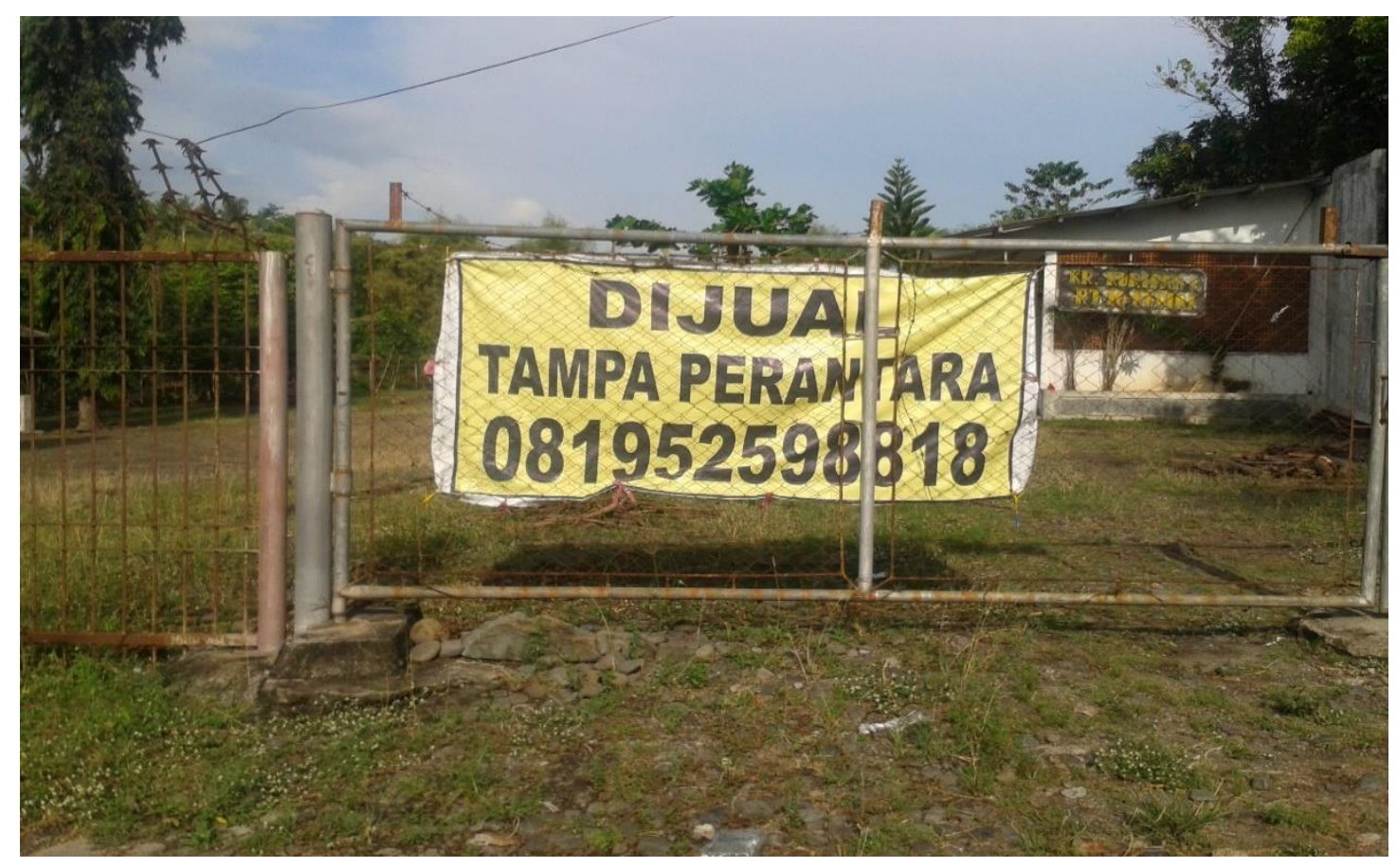

Gambar 1. Problematika bahasa Indonesia dalam tataran fonologi 
Kesalahan berbahasa yang dalam KBBI karena kata tersebut tampak pada gambar di atas adalah memang bukan termasuk kosakata perubahan fonem pada kata tampa. bahasa Indonesia. Dengan demikian, Seharusnya fonem $[\mathrm{m}]$ pada kata tampa bahasa ragam tulisan pada spanduk di pada spanduk pengumuman di atas ditulis menggunakan fonem $[n]$ sehingga menjadi kata tanpa. Dalam KBBI, kata tanpa merupakan kelas kata keterangan (adverbia) yang berarti tidak dengan; tidak ber-. Contoh pemakaian dalam kalimat menghilang tanpa bekas. Sedangkan kata tampa tidak ditemukan atas dapat diperbaiki dengan kalimat dijual tanpa perantara.

Kesalahan lain dalam tataran fonologi penulis temukan pada berkas administrasi jadwal perkuliahan sebuah perguruan tinggi. Kesalahan yang dimaksud tampak pada gambar 2 di bawah ini.

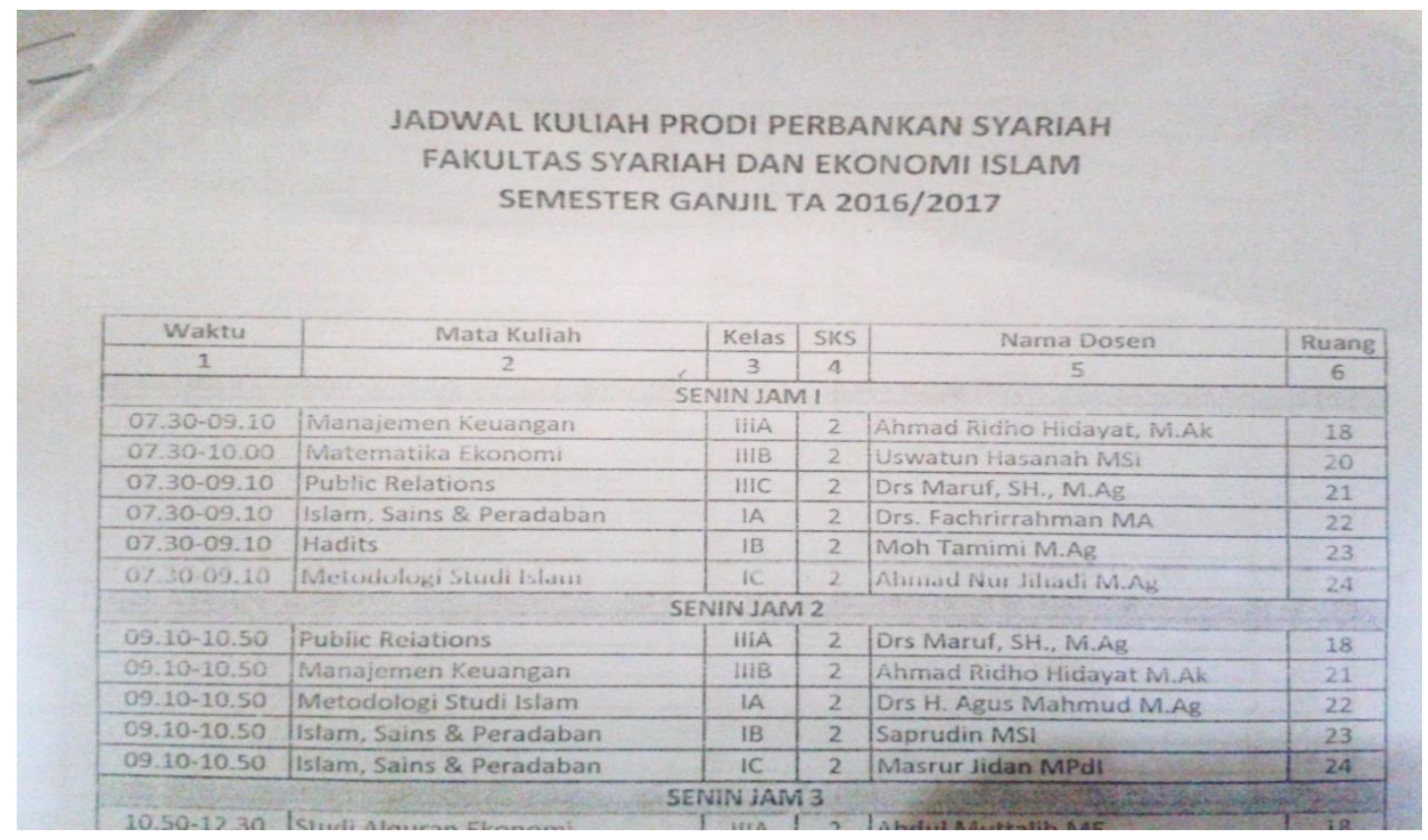

Gambar 2. Problematika bahasa Indonesia dalam tataran fonologi

Kesalahan bahasa ragam tulisan yang terdapat pada gambar 2 di atas adalah penghilangan fonem $[\mathrm{k}]$ pada kata perbankan. Seharusnya, kata tersebut ditulis dengan bentuk perbankkan karena kata tersebut merupakan bentuk turunan dari proses morfologis afiksasi yang terdiri atas kata dasar dan imbuhan konfiks. Kata dasar yang dimaksud adalah bank bukan ban 
dan imbuhan yang dimaksud adalah perkan. Kata bank dalam KBBI berarti lembaga keuangan yang usaha pokoknya memberikan pinjaman (kredit) dan jasa dalam pembayaran dan peredaran uang. Sedangkan kata perbankkan berarti hal atau segala sesuatu mengenai bank. Sementara itu, kata ban dalam KBBI berarti lingkar dari karet yang dipasang melingkar pada roda (sepeda, mobil, $d s b)$ sedangkan kata perbankan berarti hal atau segala sesuatu mengenai ban. Tentunya maksud yang ingin disampaikan oleh pengelola pendidikan dalam jadwal di atas adalah perbankkan berarti hal atau segala sesuatu mengenai bank. Dengan demikian, kesalahan ragam bahasa tulisan pada jadwal di atas dapat diperbaiki menjadi JADWAL KULIAH PERBANKKAN SYARIAH.

Beberapa contoh lain kesalahan dalam tataran fonologi yang dicontohkan Setyawati dan sering dijumpai dalam penggunaan bahasa Indonesia ragam lisan misalnya: mesjid, moril, nasehat, khutbah, tehnik, subyektif, produktifitas, jaman, kwalitas, hutang, silahkan, Jum'at, do'a, syah dan lain-lain. Untuk menghindari kesalahan berbahasa
Indonesia ragam tulisan pada tataran fonologi, kata-kata tersebut dapat diperbaiki menjadi bentuk berikut: masjid, moral, nasihat, khotbah, teknik, subjektif, produktivitas, zaman, kualitas, utang, silakan, Jumat, doa, dan sah.

\subsubsection{Problematika Bahasa Indonesia dalam Tataran Morfologi}

Kesalahan berbahasa ragam tulisan dalam tataran morfologi yang penulis temukan adalah kesalahan dalam penempatan afiks yang tidak tepat pada gabungan kata. Sebagaimana dijelaskan oleh Setyawati (2010:) kesalahan berbahasa pada tataran morfologi meliputi: (a) penghilangan afiks, (b) bunyi yang seharusnya luluh tetapi tidak diluluhkan, (c) penggantian morf, (d) pemakaian afiks yang tidak tepat, (e) penempatan afiks yang tidak tepat pada gabungan kata, (f) pengulangan kata majemuk yang tidak tepat. Gambar 3 di bawah ini merupakan salah satu bentuk kesalahan berbahasa ragam tulisan pada tataran morfologi karena pemakaian afiks yang tidak tepat, (e) penempatan afiks yang tidak tepat pada gabungan kata. 


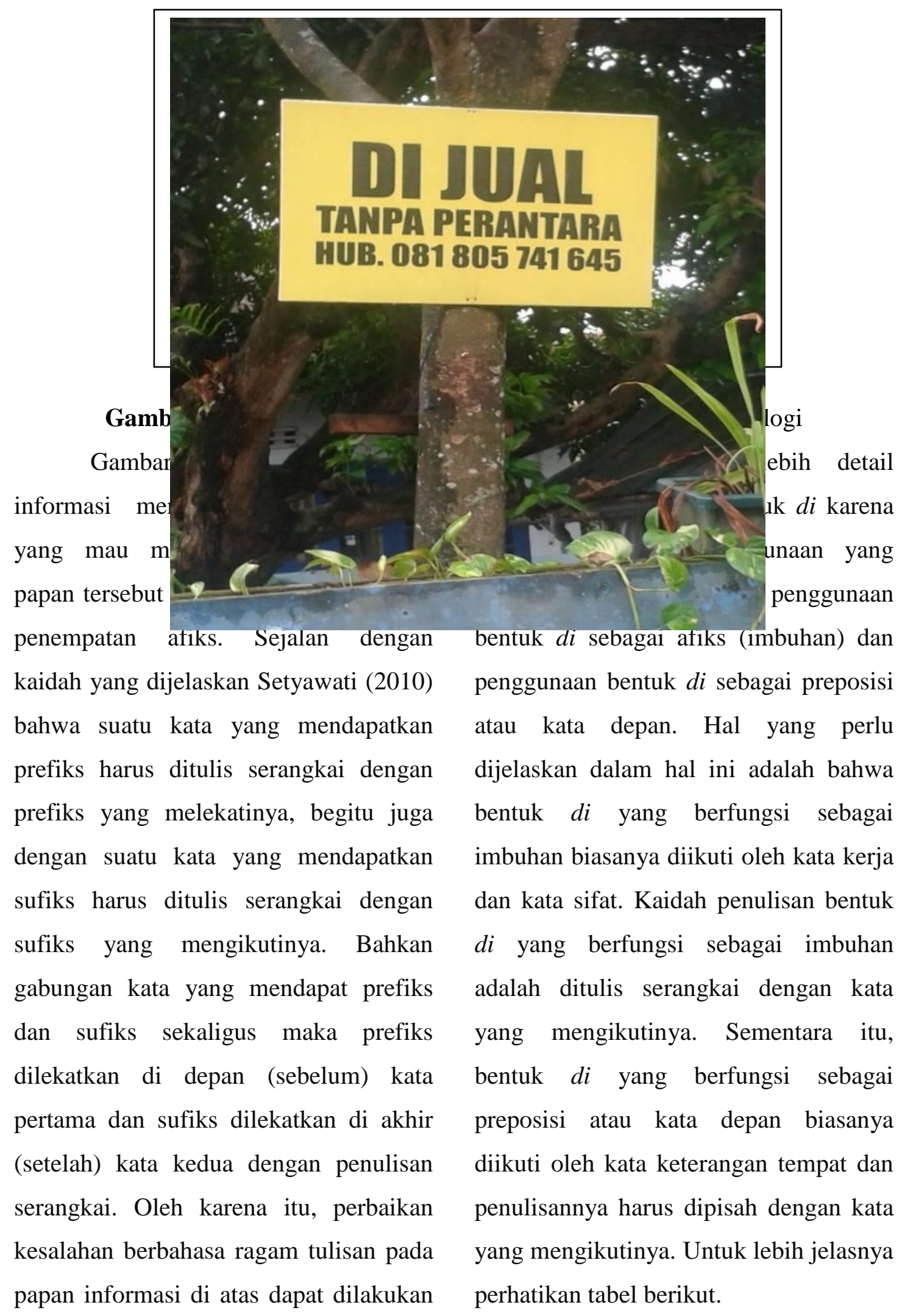

dengan mengubah bentuk tulisan menjadi dijual tanpa perantara. 
Tabel 1. Fungsi dan kaidah penulisan bentuk $d i$

\begin{tabular}{lllll}
\hline \multicolumn{1}{c}{ Fungsi $d i$} & \multicolumn{2}{c}{$\begin{array}{c}\text { Kata yang } \\
\text { mengikuti }\end{array}$} & \multicolumn{1}{c}{$\begin{array}{c}\text { Kaidah } \\
\text { penulisan }\end{array}$} & Contoh penggunaan \\
\hline sebagai imbuhan & $\begin{array}{l}\text { kata } \\
\text { sifat }\end{array}$ & kerja, kata & Serangkai & $\begin{array}{l}\text { dijual, dibaca, ditulis, } \\
\text { dll }\end{array}$ \\
& kata tempat & Dipisah & di dalam, di sekolah, \\
sebagai & & & dll \\
preposisi & & & \\
\hline
\end{tabular}

Penggunaan bentuk $d i$ yang tampak pada gambar papan informasi tumpang tindih tersebut terbukti dengan berikut. penggunaan bahasa ragam tulisan seperti

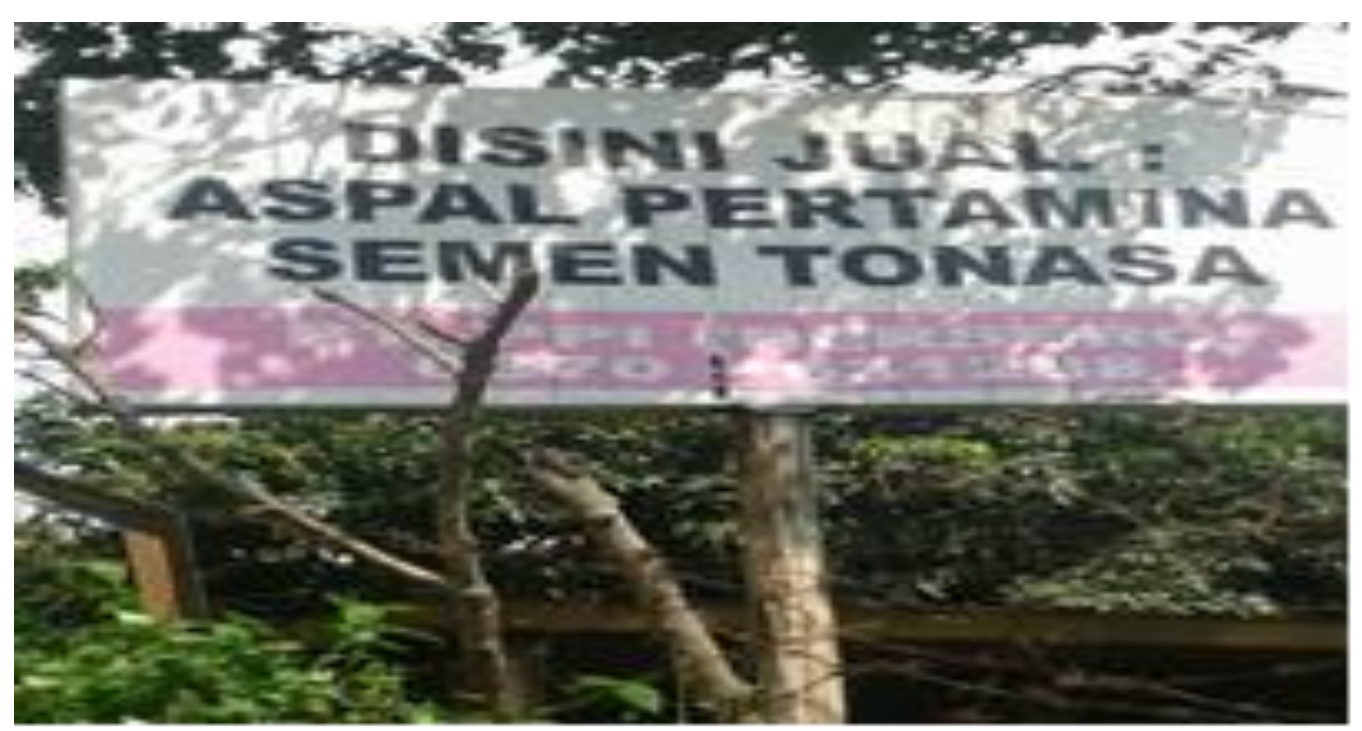

Gambar 4. Problematika bahasa Indonesia dalam tataran morfologi

Pada gambar 4 di atas, terdapat kesalahan penggunaan bentuk di yang seharusnya dipisah, namun dalam penggunaannya ditulis serangkai dengan kata yang mengikutinya. Sementara itu, pada gambar 3 di atas, penggunaan bentuk $d i$ ditulis terpisah dengan kata yang mengikutinya yang seharusnya ditulis serangkai.
Selain kesalahan dalam penggunaan bentuk di, kesalahan lain yang terdapat pada gambar 3 di atas adalah penghilangan afiks $d i$ yang seharusnya digunakan di depan kata dasar jual. Penghilangan afiks $d i$ ini menyebabkan kalimat tesebut rancu dari aspek struktur kalimat yaitu tidak adanya subjek dan predikat pada kalimat 
tersebut. Untuk menghindari kesalahan berbahasa ragam tulisan pada papan informasi di atas, kalimatnya dapat diubah menjadi di sini dijual aspal pertamina.

\subsubsection{Problematika}

Bahasa

Indonesia dalam Tataran

\section{Sintaksis}

Problematika dalam tataran sintaksis dalam penelitian ini terfokus pada dua unsur sintaksis yaitu bidang frasa dan kalimat. Klausa tidak dibahas secara tersendiri karena klausa sangat memungkinkan menjadi sebuah kalimat jika intonasinya final sehingga kesalahan berbahasa dalam bidang klausa sudah melekat pada kesalahan bidang kalimat. Hal ini sejalan dengan konsep yang ditawarkan Setyawati (2013). Kesalahan berbahasa ragam tulisan yang menyangkut frasa meliputi: (a) pengaruh bahasa daerah, (b) penggunaan preposisi yang tidak tepat, (c) susunan kata atau pola kalimat yang tidak tepat, dan (d) penggunaan unsur yang berlebihan (Akmaluddin, 2014: 89).

Adapun kesalahan dalam bidang sintaksis yang penulis temukan dalam kehidupan sehari-hari tampak pada gambar berikut.

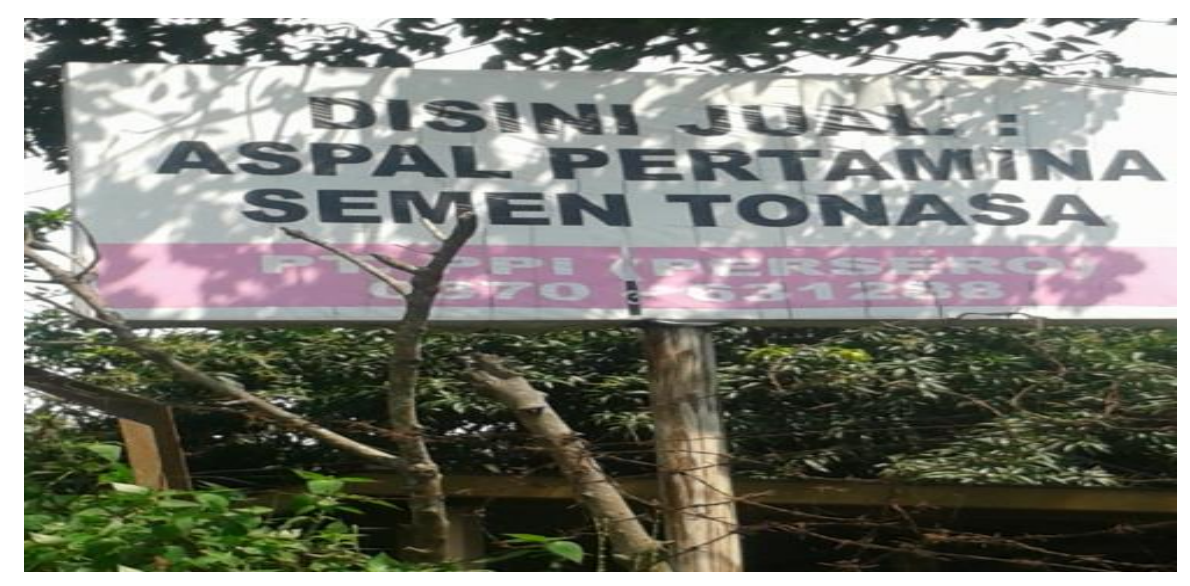

Gambar 5. Problematika bahasa Indonesia dalam tataran sintaksis

Sebagaimana dijelaskan pada yaitu penulisan bentuk di dengan kata bagian sebelumnya, bahwa pada gambar di atas terdapat kesalahan berbahasa ragam tulisan dalam hal penggunaan bentuk di. Kesalahan berbahasa ini termasuk dalam tataran sintaksis karena yang mengikutinya. Secara kaidah tata tulisan jika preposisi di melekat pada kata tempat maka penulisannya harus dipisah dengan kata yang dilekatinya. Sementara itu, pada gambar di atas dapat penulisan preposisi yang tidak tepat 
dilihat penulisan preposisi $d i$ yang tidak tepat.

Kesalahan lain yang termasuk dalam tataran sintaksis yang terdapat pada gambar 5 di atas adalah tidak adanya fungsi subjek dan predikat dalam kalimat yang tertulis pada papan informasi di atas. Sejalan dengan teori bahwa kalimat yang efektif itu seharusnya paling sedikit terdiri atas subjek dan predikat kecuali kalimat perintah atau ujaran yang merupakan jawaban pertanyaan. Biasanya kalimat yang subjeknya tidak jelas kalimat tersebut adalah kalimat yang rancu. Untuk memunculkan fungsi subjek dan predikat pada kalimat tersebut harus ditambahkan afiks di di depan kata jual. Singkatnya, agar kalimat pada papan informasi pada gambar 5 tersebut menjadi kalimat efektif, harus diubah menjadi di sini dijual aspal pertamina.

Selain berkaitan dengan ketidaklengkapan unsur kalimat, kesalahan dalam tataran sintaksis lainnya berkaitan dengan susunan kata yang tidak tepat. Gambar di bawah ini menunjukkan adanya kesalahan berbahasa ragam tulisan dalam tataran sintaksis karena ketidaktepatan susunan kata sebagai komposisi kalimat yang dibuat.

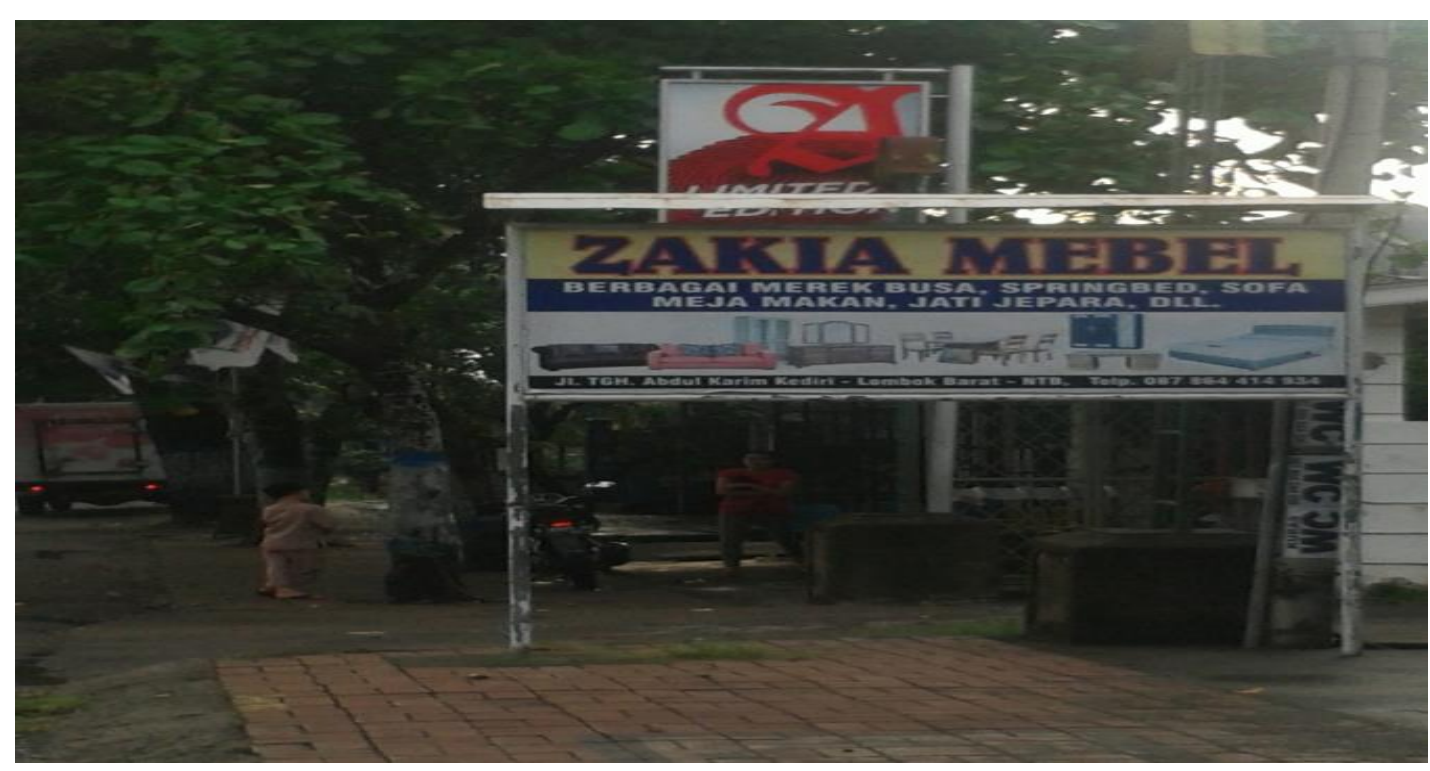

Gambar 6. Problematika bahasa Indonesia dalam tataran sintaksis

Gambar 6 di atas menunjukkan Pembentukan nama usaha tersebut masih adanya ketidaktepatan dalam terpengaruh dengan struktur bahasa pembentukan nama lembaga usaha. asing khususnya bahasa Inggris 
sedangkan kosakata yang digunakan adalah kosakata bahasa Indonesia. Hal ini memunculkan sikap tidak konsisten dalam berbahasa selain adanya pemaksaan struktur bahasa asing yang diterapkan dalam ke dalam bahasa Indonesia. Hal ini tentunya menimbulkan kesalahan dalam berbahasa Indonesia khususnya ragam bahasa tulisan. Untuk memperbaiki kesalahan tersebut, susunan yang seharusnya digunakan adalah $M E B E L$ ZAKIA. Dalam kasus ini, tentu masih banyak dijumpai kesalahan serupa sebagaimana yang dicontohkan Setyawati (2010:71) misalnya: (a) ini hari kita akan menyaksikan berbagai atraksi, (b) Seminar itu akan diselenggarakan di Anjani Kembar Hotel. Dengan demikian, perbaikan kalimat-kalimat tersebut dapat dilakukan dengan mengubah susunan kata pada kalimat tersebut sehingga menjadi (a.1) hari ini kita akan menyaksikan berbagai atraksi, (b) Seminar itu akan diselenggarakan di Hotel Anjani Kembar.

\subsubsection{Problematika Bahasa \\ Indonesia dalam Tataran Semantik}

Problematika atau kesalahan berbahasa ragam tulisan pada tataran semantik terdiri atas: (a) kesalahan penggunaan kata-kata yang mirip, (b) penggunaan kata-kata yang saling menggantikan yang dipaksakan sehingga menimbulkan perubahan makna kalimat bahkan saling merusak struktur kalimat (Setyawati, 2010). Selain itu Chaer (2002) menjelaskan bahwa salah satu peristiwa semantik yang perlu dihindari karena bermakna bias adalah ambiguitas. Ambiguitas disebabkan karena struktur kalimat yang menimbulkan penafsiran ganda. Kesalahan berbahasa ragam tulisan pada tataran semantik tampak pada gambar di bawah ini

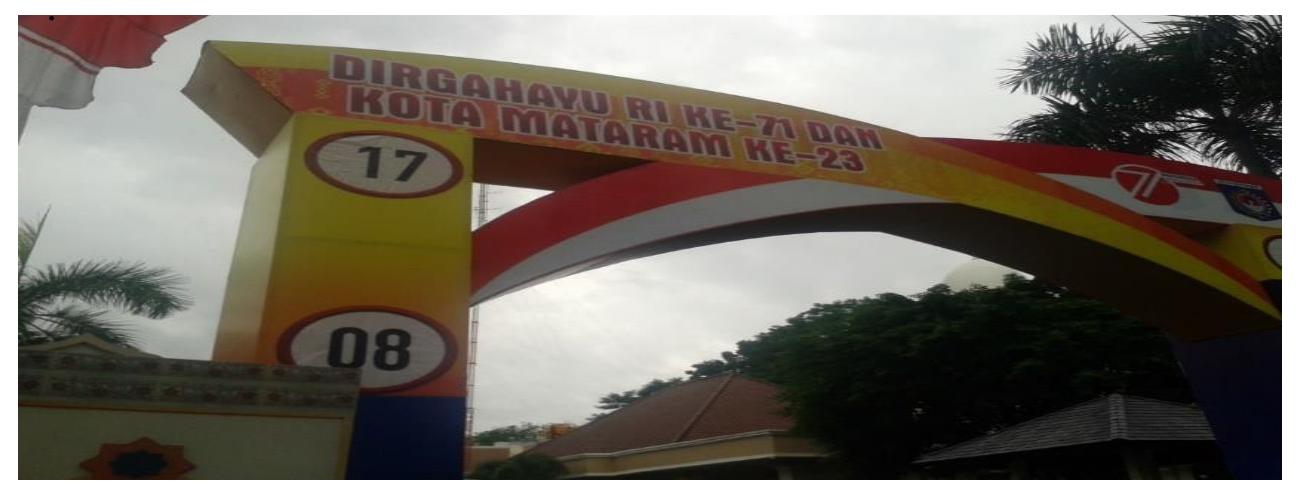

Gambar 7. Problematika bahasa Indonesia dalam tataran semantik 
Gambar 7 di atas adalah salah satu dari sekian banyak bentuk kalimat yang muncul menjelang peringatan Hari Kemerdekaan Republik Indonesia. Bentuk kalimat seperti tertera pada gambar di atas tidak begitu banyak ditulis dalam kain spanduk berbagai ukuran baik oleh lembaga resmi kenegaraan maupun swasta. Kalimat tersebut bagus, semoga menunjukkan rasa nasionalisme yang begitu tinggi dari segenap rakyat Indonesia. Namun, sebagai bangsa yang memiliki rasa nasionalisme yang tinggi, permasalahan bahasa pun seharusnya menjadi perhatian sebab bahasa adalah salah satu identitas bangsa yang harus dijaga. Dalam berbahasa tentu tidak cukup dengan pemahaman makna terhadap bentuk-bentuk bahasa yang diproduksi. Permasalahan penting lain terkait dengan bahasa adalah ketepatan penerapan kaidah yang berlaku. Penggunaan bahasa yang taat asas terhadap kaidah-kaidah bahasa Indonesia merupakan salah satu hal yang dapat memunculkan kewibaan sebagai pengguna bahasa terlebih lagi pengguna bahasa tersebut adalah lembaga resmi kenegaraan.

Kembali ke gambar 7 di atas, bahwa kalimat yang tertera pada ucapan dirgahayu RI tersebut tidak tepat secara struktur sehingga menimbulkan ambiguitas. Kegandaan makna pada kalimat di atas yaitu keterangan jumlah pada kalimat tersebut bisa jadi menerangkan peristiwa dirgahayu itu sendiri dan bisa jadi menerangkan jumlah negara RI. Makna yang ingin dimunculkan oleh pembuat ucapan tersebut tentunya dirgahayunya yang ke71, bukan Republik Indonesianya, namun makna ini tidak menjadi jelas karena struktur kalimat yang digunakan tidak tepat. Begitu juga dengan ucapan hari ulang tahun untuk kota Mataram pada ucapan tersebut, makna yang ingin dimunculkan adalah jumlah atau tingkatan peristiwa hari ulang tahunnya yang ke-23 bukan jumlah kota Mataram. Jika bentuk ucapan seperti pada gambar 7 di atas dibiarkan, orang lain bisa jadi menafsirkan bahwa ada Republik Indonesia ke-68, ke-69, dan ke-70. Selain itu ada juga, Kota Mataram ke-20, ke-21, dan ke-22, padahal baik Republik Indonesia maupun Kota Mataram hanya satu. Untuk mendapatkan bentuk ucapan yang tepat, ragam tulisan pada gamabr 7 di atas dapat diganti menjadi

DIRGAHAYU KE-71 REPUBLIK INDONESIA DAN KE-23 KOTA MATARAM 
Ambiguitas kalimat akibat penulisan huruf menjadi satuan yang ketidaktepatan penempatan unsur lebih besar, misalnya kata, kelompok kalimat seperti gambar di atas juga kata atau kalimat dalam bahasa disebutkan Arifin dan Hadi (2009:208). Indonesia. Selan itu, EYD berkatian pula Kedua pakar ini menjelaskan bahwa dengan penggunaan tada baca pada demi menghindari salah tafsir, bagian satuan-satuan huruf tersebut (Setyawati, yang menyatakan keterangan, termasuk 2010:140). Lebih lanjut, Setyawati keterangan tentang jumlah kejadian atau peristiwa harus diletakkan dengan apa yang diterangkan. Misalnya, Dies Natalis ke-8 Universitas Sanjaya, bukan Dies Natalis Universitas Sanjaya ke-8 sehingga orang tidak akan menafsirkan ada Universitas Sanjaya ke-5, ke-6, ke-7 karena, Universitas Sanjaya hanya ada satu.

\subsubsection{Problematika Bahasa Indonesia}

\section{dalam Tataran Penerapan} EYD

Ejaan Bahasa Indonesia yang Disempurnakan (EYD) merupakan seperangkat kaidah atau aturan tentang menjelaskan bahwa kesalahan berbahasa pada tataran penerapan EYD meliputi: (a) kesalahan penulisan huruf kapital, (b) kesalahan penulisan huruf miring, (c) kesalahan penulisan kata, (d) kesalahan memenggal kata, (e) kesalahan penulisan lambang bilangan, (f) kesalahan penulisan unsur serapan, dan (g) kesalahan penulisan tanda baca.

Kesalahan berbahasa ragam tulisan pada tataran penerapan EYD yang penulis temukan sebagian besar berupa kesalahan penulisan unsur serapan sebagaimana tampak pada gambar 8a dan 8b di bawah ini.

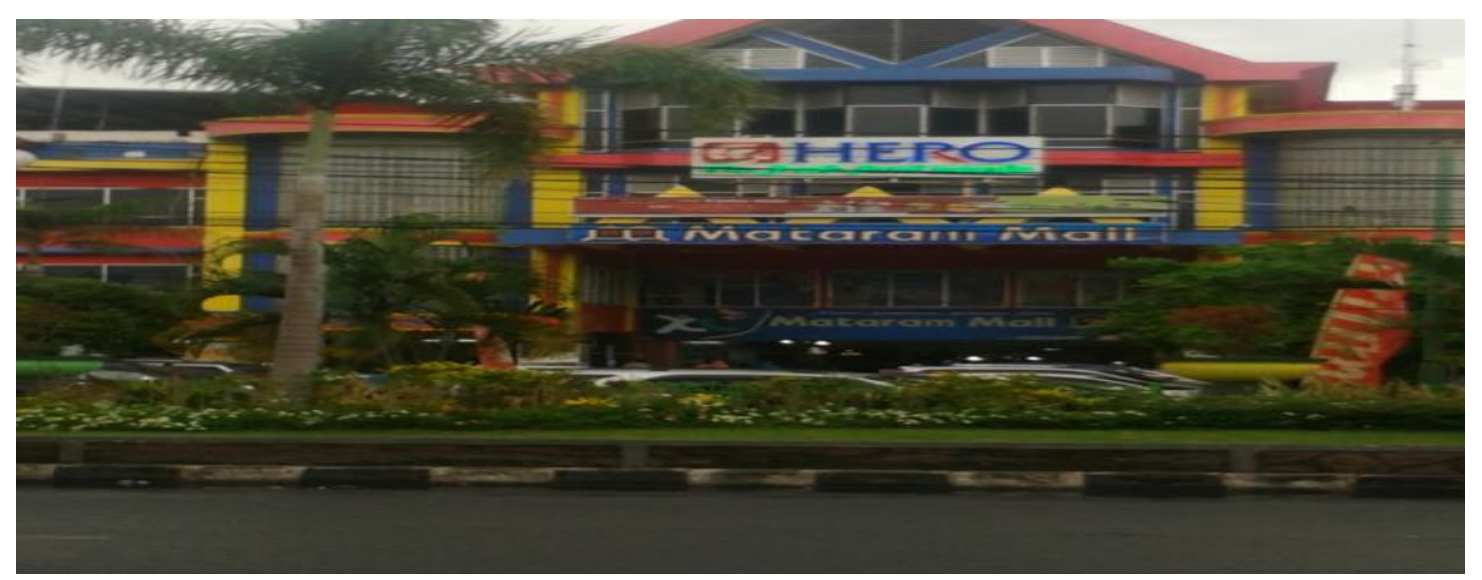

Gambar 8a. Problematika bahasa Indonesia dalam tataran penerapan EYD 


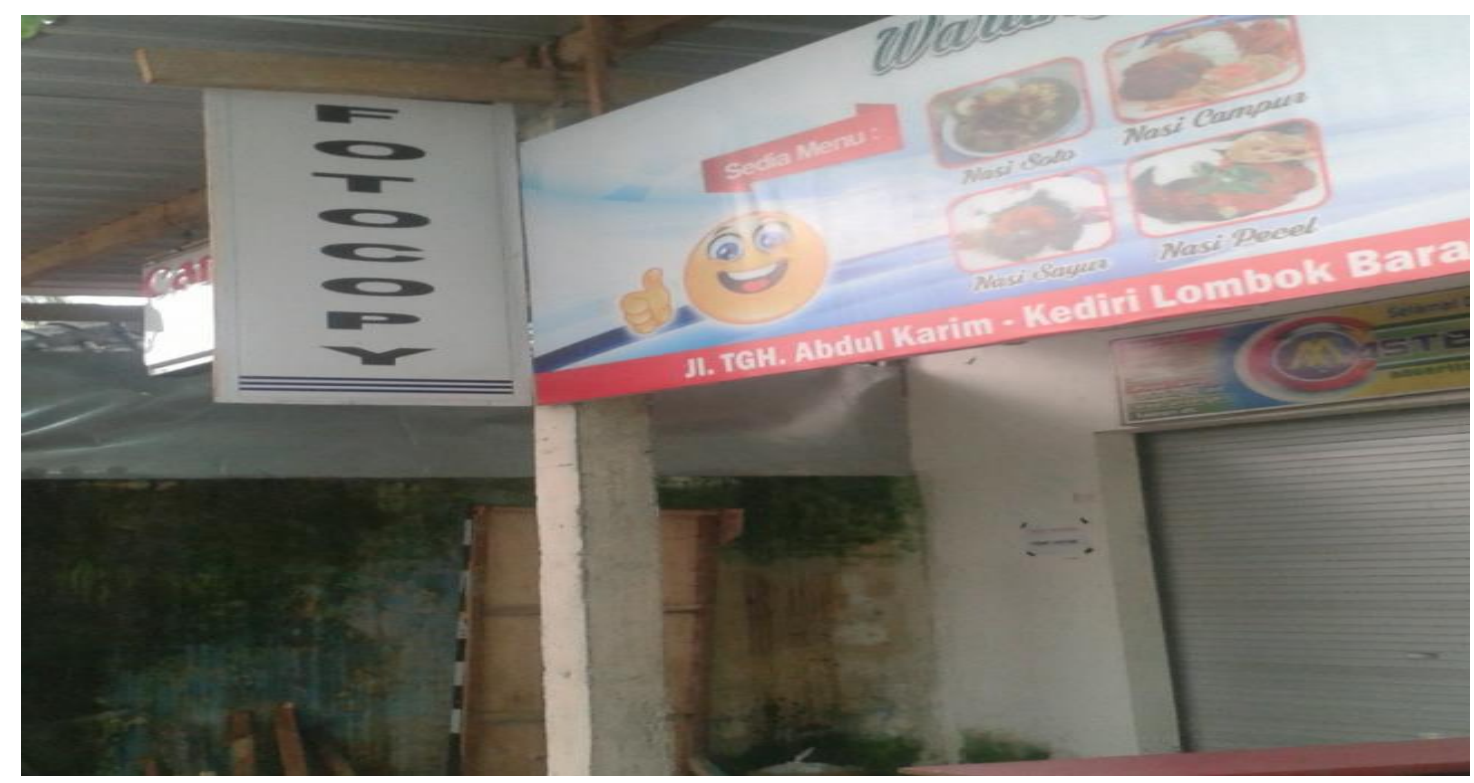

Gambar 8b. Problematika bahasa Indonesia dalam tataran penerapan EYD

Gambar 8a dan 8b di atas yang terkandung dalam bahasa asing. memperlihatkan adanya kesalahan Adapun cara kreasi dilakukan dengan berbahasa ragam tulisan dalam hal mengambil konsep dasar yang ada pada penggunaan unsur serapan. Penyerapan bahasa asing ke dalam bahasa Indonesia dilakukan dengan empat cara yaitu adopsi, adaptasi, penerjemahan, dan kreasi (Shalima dkk, 2013:34). Adopsi yaitu penyerapan bahasa asing dengan mengambil sepenuhnya suatu kosakata bahasa asing tanpa adanya perubahan atau penyesuaian dengan kaidah bahasa Indonesia. Sedangkan adaptasi dilakukan dengan adanya perubahan atau penyesuaian bentuk kosakata yang diserap dengan kaidah bahasa Indonesia. Sementara itu, cara penerjemahan dilakukan dengan mengambil konsep bahasa asing tanpa mempertimbangkan komposisi atau unsur-unsur bahasa asing yang diserap. Dalam artikel ini di bahas cara adopsi dan adaptasi. Gambar 8a dan $8 \mathrm{~b}$ di atas menunjukkan penerapan EYD dalam hal penggunaan unsur serapan yang tidak tepat.

Gambar 8a terdapat nama sebuah pusat perbelanjaan yaitu mal. (Shalima dkk, 2013:34) menyebutkan bahwa beberapa contoh kosakata yang diserap dengan cara adopsi adalah kata supermarket, palza, mal, dan hotdog. Sebagaiman dilihat pada gambar 8a di atas, unsur serapan mal ditulis dengan 
bentuk mall. Sejalan dengan teori yang dikemukakan pakar di atas bahwa seharusnya, kosakata yang diserap dengan cara adopsi kosakata tersebut tidak perlu mengalami perubahan apa pun. Dengan demikian, bentuk Mataram Mall pada gambar 8a di atas tidak sesuai dengan kaidah penulisan unsur serapan. Perbaikan kesalahan penulisan unsur serapan pada gambar 8a dapat dilakukan dengan mengubah bentuk menjadi Mal Mataram.

Berbeda halnya dengan gambar $8 \mathrm{a}$, pada gambar $8 \mathrm{~b}$ terdapat papan nama usaha fotokopi yang bertuliskan fotocopy. Bentuk fotokopi merupakan unsur serapan bahasa asing yang diserap dengan cara adaptasi dari kata photocopy. Dengan demikian, bentuk serapan yang tertulis pada papan nama usaha tersebut tidak sesuai dengan kaidah penulisan unsur serapan. Untuk memperbaiki bentuk serapan tersebut, harus diganti dengan bentuk yang telah diadaptasikan dengan kaidah bahasa Indonesia yaitu fotokopi. Beberapa bentuk penulisan unsur serapan yang tidak sesuai dengan kaidah bahasa Indonesia namun sering kita jumpai sebagaimana disebutkan Sabariyanto (2001) adalah: aktifitas, analisa, bis/bas/bes, cendera mata, dharma bhakti, elit, filem, gubenur, hirarki, ihlas, Jum'at, khutbah, lokalisir, madia, non aktif, oase, paskasarjana/pasca sarjana, Qur'an, Ramadhan/Romadlon, varitas, waqaf, juridis, jaman. Untuk memperbaiki bentuk-bentuk serapan tersebut harus diganti dengan bentuk sebagai berikut: aktivitas, analisis, bus, cenderamata, darmabakti, elite, film, gubernur, hierarki, ikhlas, Jumat, khotbah, lokalisasi, madya, nonaktif, oasis, pascasarjana, Quran, Ramadan, varietas, wakaf, yuridis, zaman.

\subsection{Faktor-Faktor \\ Penyebab \\ Kesalahan Berbahasa Ragam Tulisan}

Berdasarkan penjelasan di atas, pada penelitian ini dapat diidentifikasi beberapa faktor penyebab kesalahan berbahasa khususnya ragam tulisan pada berbagai tataran linguistik. Hal ini sebagaimana disebutkan pula oleh Akmaluddin (2014) dalam penelitian sebelumnya. Faktor-faktor yang dimaksud sebagai berikut.

1) Minimnya Pengetahuan Mayarakat tentang tata bahasa Indonesia yang Sesuai dengan EYD

Kesalahan berbahasa ragam terjadi karena kurangnya pengetahuan masyarakat tentang kaidah bahasa Indonesia yang baik dan benar. 
Terutama dalam hal penulisan atau penggunaan unsur-unsur serapan. Data yang didapatkan peneliti dalam artikel ini adalah sebagian kecil dari gambaran penggunaa bahasa Indonesia ragam tulisan oleh pengguna bahasa Indonesia. Jika mengacu pada hasil penelitian Akmaluddin (2014) akan ditemukan simpulan bahwa kesalahan bahasa tulisan yang ditemukan pada dokumen dinas tersebut sebanyak 185 yang terdiri atas kesalahan dalam bidang EYD sebanyak 145, kesalahan dalam bidang morfologi sebanyak 7 , kesalahan dalam bidang sintaksis sebanyak 14, dan kesalahan dalam bidang semantik sebanyak 19. Kesalahan berbahasa dalam bidang EYD terdiri atas penggunaan huruf kapital sebanyak 26 kesalahan, penggunaan tanda titik sebanyak 34 kesalahan, penggunaan tanda titik koma sebanyak 12 kesalahan, penggunaan cetak miring sebanyak 10 kesalahan, dan penulisan kata sebanyak 82 kesalahan. Selain adanya kesalahan berbahasa tulisan dalam dokumen dinas tersebut, juga terdapat kesilapan yang terdiri atas 4 kata. Semua kesalahan ini hanya di lingkup Sekda Pemkot Mataram belum lagi kesalahan berbahasa ragam tulisan di lembaga lain.
2) Asumsi yang Keliru terhadap Bahasa Indonesia

Selain karena minimnya teori ketatabahasaan, faktor penyebab kesalahan berbahasa Indonesia ragam tulisan adalah asumsi yang keliru terhadap bahasa Indonesia. Asumsi yang keliru ini menyebabkan sikap bahasa yang negatif pada pengguna bahasa Indonesia. Sikap negatif ini ditandai dengan lebih memilih menggunakan kosakata dan struktur bahasa asing daripada bahasa Indonesia. Beberapa contoh di atas seperti: zakia mebel, fotocopy, Mataram Mall adalah penggunaan struktur bahasa asing. Data ini pun adalah sebagian kecil dari penggunaan bahasa Indonesia karena tidak semua data bisa terdokumentasi peneliti.

\section{Penutup}

Problematika bahasa Indonesia yang ditandai dengan kesalahan berbahasa khususnya ragam tulisan terjadi pada berbagai tataran linguistik sebagaimana simpulan berikut.

1) Kesalahan berbahasa ragam tulisan pada tataran fonologi, misalnya penggunaan bentuk tampa dan perbankan. 
2) Kesalahan berbahasa ragam tulisan pada tataran morfologi, misalnya kesalahan dalam penulisan kata berimbuhan yaitu seperti terlihat pada penggunaan bentuk di jual.

3) Kesalahan berbahasa ragam tulisan pada tataran sintaksis, seperti terlihat pada penggunaan bentuk disini, dan zakia mebel.

4) Kesalahan berbahasa ragam tulisan pada tataran semantik, seperti terlihat pada penggunaan bentuk Dirgahayu RI ke-71 dan Kota Mataram ke-23.

5) Kesalahan berbahasa ragam tulisan pada tataran penerapan EYD, seperti terlihat pada penggunaan bentuk Mataram Mall, fotocopy, aktifitas, analisa, bis/bas/bes, cendera mata, dharma bhakti, elit, filem, gubenur, hirarki, ihlas, Jum'at, khutbah, lokalisir, madia, non aktif, oase, paskasarjana/pasca sarjana, Qur'an, Ramadhan/Romadlon, varitas, waqaf, juridis, dan jaman.

Kesalahan-kesalahan berbahasa Indonesia ragam tulisan disebabkan oleh dua faktor yaitu minimnya pengetahuan mayarakat tentang tata bahasa Indonesia yang sesuai dengan EYD dan adanya asumsi yang keliru terhadap bahasa Indonesia.

\section{Daftar Pustaka}

Akmaluddin. (2014). "Analisis Kesalahan Bahasa Tulisan pada Naskah Dinas di Sekretariat Daerah Pemkot Mataram dan Relevansinya terhadap Pembelajaran Bahasa Indonesia pada Jenjang Pendidikan Menengah". Tesis Magister Pendidikan Bahasa Indonesia pada Program Pascasarjana Universitas Mataram: tidak diterbitkan.

Alwi, Hasan dkk.. (2003). Tata Bahasa Baku Bahasa Indonesia. Jakarta: Balai Pustaka.

Arifin, E. Zainal dan Farid Hadi. (2009). 1001 Kesalahan Berbahasa. Jakarta: Akademika Pressindo.

Arikunto, Suharsimi. (2013). Prosedur Penelitian Suatu Pendekatan Praktik. Jakarta: Rineka Cipta.

Chaer, Abdul. (2002). Pengantar Semantik Bahasa Indonesia. Jakarta: Reineka Cipta.

Tarigan, Djago dan Lilis Siti Sulistyaningsih. (1998). Analisis Kesalahan Berbahasa. Jakarta: Departemen Pendidikan dan Kebudayaan Direktorat Jenderal Pendidikan Dasar dan Menengah.

Haimun. (2014). "Penggunaan Bahasa Indonesia dalam Karya Tulis Ilmiah Guru Pembina Golongan IV/a dan Pembelajarannya di Sekolah Menengah Atas di Kota Mataram Tahun 2013”. Tesis Magister Pendidikan Bahasa Indonesia pada Program Pascasarjana Universitas Mataram: tidak diterbitkan. 
Ramlan, M.. (2001). Morfologi Suatu Tinjauan Deskriptif. Yogyakarta: CV. Karyono.

Sabariyanto, Dirgo. (2001). Mengapa Disebut Kata Baku dan Tidak Baku. Jakarta: Mitra Gama Media.

Setyawati, Nanik. (2010). Analisis Kesalahan Berbahasa Indonesia Teori dan Praktik. Surakarta: Yuma Pustaka.

Shalima, Irsyadi dkk.. (2013). DetikDetik Ujian Nasional Bahasa Indonesia. Klaten: PT Intan Pariwara.

Sudaryanto. (2015). Metode dan Aneka Teknik Analisis Bahasa; Pengantar Penelitian Wahana Kebudayaan secara Linguistik. Yogyakarta: Sanata Dharma University Press.

Tim Penyusun Kamus Pusat Bahasa. (2008). Kamus Bahasa Indonesia. Jakarta: Pusat Bahasa. 